\title{
Pengaruh Budaya Organisasi Terhadap Agilitas Organisasi (Study Pada Fashion X)
}

\author{
Oleh: \\ Fuzi Fauziyyah dan Sri Raharso \\ Politeknik Negeri Bandung
}

\begin{abstract}
An organization has characteristic or particular identity for the purpose of uniting its members so as to have an overview on running the organization as reflected by the organizational culture in it. Strong organizational culture is one way to achieve agility, the new management approach to deal with changes. This research aimed to find out how the organizational culture and organizational agility and the influence of organizational culture on organizational agility in the case study at Fashion X. In this research method used quantitative and descriptive method and using questionnaires that distributed to 131 respondents and interviews. The study states that the organizational culture and organizational agility in Fashion $X$ quite good, even though it needs upgrading for adhocracy, hierarchy, and competency. Both variables have strong positive relationship amounted to 0,548 and in Fashion X 30\% organizational agility affected by organizational culture. Additionally regression equation $Y=64.323+0,657 X$. Organizational culture can be improved by increasing risk-taking by creating small teams, develop products, gathering, team building to enhance the innovative thought leaders, improving the way for more efficient delivery of goods, execution, product's strategy, situational leadership, technology, the power of employees, organizational ability, organizational changes, and customer's services.
\end{abstract}

Keywords: organizational agility, organizational culture

\section{Latar Belakang Penelitian}

Organisasi merupakan wadah pembentukan tingkah laku hubungan antar manusia secara efektif sehingga dapat bekerja sama secara efisien dan memperoleh kepuasan pribadi dalam melaksanakan tugas-tugasnya, serta memberikan kondisi lingkungan tertentu untuk mencapai tujuan (Herujito, 2001: 110). Setiap organisasi tentu memiliki ciri khas yang menggambarkan bagaimana organisasi tersebut, hal itu dinamakan budaya organisasi (Suparjati, 2000: 1).

Budaya organisasi dapat menjadi instrumen keunggulan kompetitif yang utama, yaitu bila budaya organisasi mendukung strategi organisasi, dan bila budaya organisasi dapat menjawab atau mengatasi tantangan lingkungan dengan cepat dan tepat (Soedjono, 2005: 23). Budaya organisasi menciptakan suatu perbedaan yang jelas dengan organisasi lainnya. Selain itu budaya organisasi merupakan identitas organisasi tersebut (Robbins, 2013: 294). Adanya identitas yang menjadikan pembeda, maka organisasi mempunyai ciri khas sendiri sehingga budaya organisasi dapat menjadi sumber keuntungan yang kompetitif. Hal tersebut dapat menjadikan budaya organisasi sebagai salah satu cara untuk bertahan dalam persaingan dan perubahan lingkungan strategi bisnis (Amirnejad dan Milad, 2005: 1530).

Perubahan lingkungan berdampak pada tingginya tingkat persaingan dalam menjalankan bisnis yangmenjadikan organisasi berada dalam lingkungan yang dinamis. Dengan demikian, untuk menghadapi perubahan, intensitas persaingan yang tinggi, dan lingkungan yang dinamis maka organisasi akan lebih baik menerapkan pendekatan baru sebagai solusinya, yaitu agilitas. Agilitas didefinisikan sebagai kemampuan untuk bertahan 
dan berhasil dalam lingkungan perubahan kompetitif yang terus menerus dan tak terduga dengan reaksi cepat dan efektif untuk merubah pasar dengan mengendalikan produk dan pelayanan yang telah ada (Gunasekaran, 1999: 88). Pada prinsipnya, budaya organisasi dapat membantu mengatasi masalah adaptasi eksternal. Organisasi harus mampu beradaptasi dan menangkap peluang dengan cepat sehingga dapat mencapai agilitas organisasi (O'brien, 2005: 334).

Fashion $\mathrm{X}$ merupakan salah satu perusahaan retail dalam bidang fashion yang berfokus pada kerudung. Budaya organisasi di Fashion X meliputi fokus konsumen, fokus kualitas, dan fokus tenaga kerja. Schein (2004: 25) menyatakan bahwa budaya organisasi terdiri dari tiga lapisan yaitu artefacts, espoused values, dan underlying assumption. Di Fashion X untuk penerapan artefacts seperti struktur organisasi memang belum maksimal dikarenakan Fashion $\mathrm{X}$ belum dapat menemukan pola struktur organisasi yang tepat, tetapi untuk produk-produk yang dihasilkan sudah dikenal baik oleh masyarakat luas. Penerapan berikutnya adalah espoused values, dimana tingkatan ini nilai-nilai organisasi harus ditanamkan oleh anggotanya. Berdasarkan hasil pengamatan, nilai-nilai organisasi yang dimiliki oleh Fashion X secara keseluruhan belum diterapkan dengan baik oleh anggotanya. Salah satu budaya organisasi Fashion $X$ adalah fokus pada tenaga kerja yang membentuk tenaga kerja yang kuat aqidah, ruqiyah, dan jasad-nya, akan tetapi dalam mengamalkan amalan seperti puasa Senin-Kamis belum diterapkan oleh semua anggota. Terakhir penerapan underlying assumption sebagai bentuk keyakinan yang harus ada dalam diri tiap-tiap anggota mengenai organisasi pun belum diterapkan dengan baik oleh anggota, misalnya Fashion X mempunyai keyakinan bahwa kerja itu sebagai ibadah akan tetapi masih ada anggota yang belum memiliki keyakinan seperti itu. Hal tersebut ditandai dengan belum dilakukan secara maksimal nilai-nilai yang ada dalam organisasi.

Berdasarkan kuesioner pra penelitian yang disebar kepada 30 karyawan Fashion X secara acak, untuk budaya organisasi diperoleh hasil bahwa 76,7\% responden berpendapat bahwa Fashion $\mathrm{X}$ merupakan organisasi seperti keluarga, 36,7\% responden menyatakan Fashion X merupakan organisasi yang menuntut anggotanya mengambil resiko, 66,7\% responden berpendapat bahwa Fashion $\mathrm{X}$ merupakan organisasi yang dikendalikan atas kompetisi, dan 23,3\% responden menyatakan bahwa Fashion X merupakan organisasi yang lebih formal dan terstruktur.

Untuk agilitas organisasi hasil yang didapat adalah 50\% responden Fashion X menyatakan bahwa tanggapan Fashion $\mathrm{X}$ terhadap perubahan belum cepat, belum reaktif, dan belum produktif. Selanjutnya $73,7 \%$ responden Fashion $\mathrm{X}$ menyatakan bahwa sumber daya manusia yang dimiliki oleh Fashion $\mathrm{X}$ belum kompeten. Hasil kuesioner pra penelitian lainnya adalah 43,3\% responden menyatakan Fashion X kurang cepat dalam meluncurkan produk baru ke pasar serta kurang cepat dalam hal pengiriman barang dan $40 \%$ responden menyatakan bahwa Fashion X kurang fleksibel, seperti mengubah waktu pengiriman, transfer karyawan antar unit yang sulit dilakukan, dan karyawan belum dapat melakukan berbagai jenis aktivitas secara efektif.

Berdasarkan fenomena tersebut, maka tujuan penelitian ini adalah untuk mengidentifikasi pengaruh budaya organisasi dan agilitas organisai di Fashion X. Selain itu, untuk mengetahui bagaimana kondisi budaya organisasi dan agilitas organisasinya.

\section{Budaya Organisasi}

Manusia dalam kesehariannya terbentuk oleh lingkungan yang menyebabkan timbulnya sikap dan perilaku tertentu. Salah satu lingkungan tersebut adalah tempat kerja yang menentukan dan membentuk anggotanya oleh budaya organisasi. Budaya organisasi yang kuat dalam organisasi - yaitu paling tidak mampu mengikat seluruh anggotanya, dapat 
memberikan paksaan atau dorongan kepada para anggotanya untuk bertindak atau berperilaku sesuai dengan yang diharapkan oleh organisasi (Moeljono, 2005: 97).

Budaya organisasi memiliki banyak definisi. Schein (2004: 17) mendefinisikan budaya organisasi sebagai pola dari asumsi-asumsi dasar yang ditemukan, diciptakan atau dikembangkan oleh suatu kelompok tertentu, dengan maksud agar organisasi belajar mengatasi dan menganggulangi masalah-masalah yang timbul akibat adaptasi eksternal dan integrasi internal yang sudah berjalan dengan cukup baik, sehingga perlu diajarkan kepada anggota-anggota baru sebagai cara yang benar untuk memahami, memikirkan, dan merasakan berkenaan dengan masalah-masalah tersebut. Schein (2004: 25) juga menyatakan bahwa budaya terdiri dari tiga lapisan atau tingkatan, yaitu: (a) Artefacts, tingkat pertama/atas dimana kegiatan atau bentuk organisasi terlihat seperti struktur organisasi maupun proses, lingkungan fisik organisasi dan produk-produk yang dihasilkan.(b) EspousedValues, tingkat kedua adalah nilai-nilai yang didukung, terdiri daristrategi, tujuan, dan filosofi organisasi. Tingkat ini mempunyai arti penting dalamkepemimpinan, nilai-nilai ini harus ditanamkan pada tiap-tiap anggota organisasi.(c) UnderlyingAssumption, asumsi yang mendasari, yaitu suatu keyakinan yangdianggap sudah harus ada dalam diri tiap-tiap anggota mengenai organisasi yangmeliputi aspek keyakinan, pemikiran dan keterikatan perasaan terhadap organisasi.

Brown (1998: 9) mendefinisikan budaya organisasi sebagai pola keyakinan, nilainilai, dan belajar cara mengatasi pengalaman yang telah dikembangkan selama sejarah organisasi, dan cenderung diwujudkan dalam pengaturan materi dalam perilaku anggotanya. Werner (2007: 25) menyatakan bahwa para pemimpin organisasi perlu menentukan jenis budaya yang akan mencerminkan visi dan nilai-nilai organisasi, mengidentifikasi perilaku yang tepat untuk membentuk budaya dan kemudian mengembangkan strategi untuk menanamkan perilaku di seluruh organisasi.

Banyak cara untuk mengidentifikasi budaya organisasi salah satunya menggunakan metode OCAI (Organizational Culture Assessment Instrument) atau yang dikenal juga dengan CVF (Competing Values Framework) yang dikembangkan oleh Cameron dan Quinn (2006). CVF terdiri dari dua dimensi. Dimensi pertama terkait dengan penekanan pada fleksibilitas, kebijaksanaan, dinamisme dari penekanan stabilitas, ketertiban, dan kontrol. Dimensi yang kedua membedakan orientasi internal dengan fokus pada integrasi, kolaborasi, kesatuan dari orientasi eksternal dengan fokus pada diferensiasi, dan persaingan ( $\mathrm{Yu}$ dan Nengquan, 2009: 38). Kemudian kedua dimensi tersebut, satu ditarik secara vertikal dan satu lagi ditarik secara horizontal sehingga mengakibatkan terbentuknya empat kuadran, yaitu clan, adhocracy, market, dan hierarchy (Cameron dan Quinn, 2016: 3).

Dimensi pertama adalah clan. Menurut Cameron dan Quinn (2006: 41), dimensi clan memiliki internal yang fokus dan lebih menghargai fleksibilitas daripada stabilitas dan kontrol. Kebudayaan ini mirip dengan organisasi tipe keluarga dimana efektivitas dicapai dengan mendorong kerja sama antar anggota. Tipe kebudayaan ini sangat berorientasi pada anggotanya dan berusaha untuk memenuhi kepaduan melalui mufakat dan kepuasan pekerjaan serta komitmen melalui keterlibatan anggota. Organisasi-organisasi clan sedapat mungkin memberikan sumber-sumber untuk merekrut dan mengembangkan anggota-anggota mereka, serta melihat para pelanggan sebagai rekan kerja.

Masih menurut Cameron dan Quinn (2006: 43) dimensi yang kedua yaitu adhocracy yang memiliki nilai eksternal dan menghargai fleksibilitas. Tipe kebudayaan ini membantu perkembangan penciptaan produk-produk dan layanan yang inovatif dengan menyesuaikan diri, kreatif, dan cepat menanggapi perubahan pasar. Kebudayaan adhocracy tidak bergantung pada tipe kekuatan yang terpusat dan hubungan kekuasaan yang merupakan bagian dari pasar dan kebudayaan hirarkis. Kebudayaan ini juga mendorong para anggota untuk mengambil resiko apa pun, berpikir di luar kebiasaan, dan bereksperiman dengan cara 
baru dalam menyelesaian sesuatu. Tipe kebudayaan ini cocok untuk organisasi-organisasi baru, organisasi-organisasi dalam industri-industri yang mengalami perubahan konstan, dan organisasi-organisasi dalam industri-industri yang sedang tumbuh yang membutuhkan inovasi untuk meningkatkan pertumbuhan.

Selanjutnya dimensi yang ketiga yaitu market. Memiliki fokus eksternal yang kuat serta menghargai stabilitas dan kontrol. Organisasi-organisasi dengan kebudayaan ini dikendalikan atas kompetisi dan hasrat yang kuat untuk mengantarkan hasil dan mencapai tujuan. Karena tipe ini berpusat pada lingkungan eksternal, pelanggan dan keuntungan harus didahulukan daripada pengembangan dan kepuasan anggota. Tujuan utama para manager adalah mendorong produktivitas, keuntungan, dan kepuasan pelanggan. Para anggota diharapkan untuk bereaksi secara cepat, bekerja keras, dan mengantarkan kualitas tepat waktu. Organisasi-organisasi dengan kebudayaan ini cenderung memberi penghargaan kepada orang-orang yang memberikan hasil (Cameron dan Quinn, 2006: 37).

Terakhir menurut Cameron dan Quinn (2006: 39) dimensi yang keempat yaitu hierarchy yang memiliki fokus internal yang menghasilkan keuntungan kerja yang lebih formal dan terstruktur, serta menghargai stabilitas dan kontrol lebih dari fleksibilitas. Orientasi ini membawa pada perkembangan proses internal yang dapat diandalkan, ukuran yang ekstensif, dan implementasi dari beragam mekanisme kontrol. Efektivitas dalam sebuah organisasi dengan tipe kebudayaan ini kemungkinan besar dinilai dengan ukuran efisiensi, ketepatan waktu, serta ketergantungan atas produk-produk dan layanan yang dihasilkan dan diantar.

\section{Agilitas Organisasi}

Perubahan yang cepat dan drastis dalam sektor industri membuat organisasi menghadapi tantangan baru dan dalam hal ini pembentukan agilitas dalam sebuah organisasi sangat diperlukan. Alberts dan Hayes (2003: 153) menjelaskan bahwa agilitas organisasi merupakan kapasitas untuk mengubah organisasi dan aturan bisnis yang bilamana beroperasi membuat lebih efektif dan efisien ketika berhadapan dengan berbagai jenis hal yang harus dilakukan oleh organisasi. Kapasitas tersebut membuat organisasi menjadi lebih responsif, fleksibel, dan inovatif. Agilitas organisasi dianggap sebagai kompetensi inti, keunggulan kompetitif, dan pembeda yang membutuhkan pemikiran strategis, pola pikir yang inovatif, memanfaatkan perubahan dan kebutuhan yang tiada henti untuk beradaptasi dan proaktif (Harraf et al., 2015: 675). Kelincahan organisasi didefinisikan sebagai kemampuan organisasi untuk menghadapi perubahan yang sering muncul secara tiba-tiba dalam lingkungan bisnis melalui respon yang cepat dan inovatif yang mengeksploitasi perubahan sebagai kesempatan untuk tumbuh dan sejahtera (Lu dan Ramamurthy 2011: 933).

Ada beberapa kunci konsep penentu agilitas menurut Sanchuli dan Yazdani (2015: 189), yaitu manajemen kunci kompetensi, organisasi virtual, kemampuan untuk restrukturisasi, dan organisasi berbasis pengetahuan. Pertama, manajemen kunci kompetensi merupakan konsep pertama di belakang paradigma agilitas. Misalnya, kompetensi utama anggota organisasi meliputi keterampilan, pengetahuan, perilaku, dan pengalaman. Kedua, organisasi virtual, yang memiliki ciri khas menggunakan struktur virtual. Dalam hal ini organisasi memanfaatkan teknologi informasi, seperti internat, e-mail, dan meluasnya penggunaan komputer menyebabkan bentuk organisasi memiliki sifat yang berbeda dari organisasi tradisional.

Selanjutnya masih dalam Sanchuli dan Yazdani (2015: 189) konsep yang ketiga adalah kemampuan untuk restrukturisasi. Organisasi yang tangkas dapat dengan mudah membuat perubahan signifikan dalam fokus, diversifikasi dan modernisasi bisnis dalam rangka mempercepat proses pencapaian tujuan. Organisasi yang mampu restrukturisasi berada dalam situasi yang baik dan memiliki keuntungan seperti kecepatan, mendominasi 
pasar, dan agilitas melalui penggagas sebuah produk yang dibutuhkan konsumen sebelum mereka mengungkapkan kebutuhannya. Terakhir, organisasi berbasis pengetahuan. Organisasi yang ingin mencapai agilitas harus meng-upgrade anggotanya agar termotivasi dengan baik dan dilatih dengan keterampilan, pengalaman, dan pengetahuan yang tepat.

Dalam mengidentifikasi dan penerapkan agilitas organisasi, Zhang dan Sharifi (2000: 502) mengungkapkan karakteristik untuk mencapai agilitas organisasi yaitu responsiveness, competency, quickness, dan flexibility. Responsiveness, yaitu kemampuan untuk mengidentifikasi perubahan dan menanggapi perubahan tersebut dengan cepat, reaktif atau proaktif. Competency, yaitu kemampuan untuk secara efektif mewujudkan tujuan organisasi. Dengan kata lain kompetensi adalah daftar ekstensif kemampuan yang memberikan organisasi dengan produktivitas, efisiensi, dan efektivitas dalam mencapai tujuan dan sasaran. Kompetensi ini meliputi visi strategis, kemampuan teknologi yang memadai, dan efektivitas biaya (Zhang dan Sharifi, 2000: 502).

Masih dalam Zhang dan Sharifi (2000: 502), menjelaskan bahwa quickness, yaitu kemampuan untuk menyelesaikan suatu kegiatan secepat mungkin yang meliputi kecepatan dalam memasarkan produk ke pasar, kecepatan dan ketepatan waktu dalam produk dan pelayanan. Flexibility, yaitu kemampuan untuk melaksanakan proses yang berbeda dan menerapkan fasilitas yang berbeda untuk mencapai tujuan yang sama, hal ini meliputi volume produk yang fleksibel dan orang yang memiliki fleksibilita

\section{Metode Penelitian}

Penelitian ini menggunakan metode yang bersifat kuantitatif dengan mendeskripsikan mengenai implementasi variabel budaya organisasi, variabel agilitas organisasi, dan pengaruh antara kedua variabel. Data berasal dari data primer dan sekunder yang dikumpulkan dengan cara wawancara dan menyebarkan kuesioner terhadap sampel sejumlah 131 karyawan menggunakan teknik sampling kuota. Hasil sampel tersebut merupakan hasil dari perhitungan jumlah populasi 193 karyawan dengan menggunakan rumus Slovin.

Kuesioner yang digunakan dalam penelitian ini merupakan kueisoner yang valid karena nilai seluruh instrumen memiliki nilai corrected item-total correlation lebih dari $\mathrm{r}_{\text {tabel }}$ $(0,1716)$. Selain itu, kuesioner pun memiliki tingkat reliabel yang baik karena nilai dari cronbach's alpha yaitu 0,877 untuk budaya organisasi dan 0,904 untuk agilitas organisasi lebih dari 0,800 (Sekaran, 2003: 182). Sedangkan untuk analisis data yang digunakan terdiri dari analisis korelasi, analisis regresi sederhana, koefisien determinasi, dan uji hipotesis menggukana uji F dan uji t.

\section{Hasil Identitas Responden}

Berikut ini disajikan identitas responden berdasarkan jenis kelamin, usia, pendidikan terakhir, dan masa kerja.

Tabel 1

Identitas Responden

\begin{tabular}{|l|l|c|c|}
\hline \multicolumn{1}{|c|}{ Identitas } & Keterangan & Responden & Persentase \\
\hline \multirow{4}{*}{ Jenis Kelamin } & Pria & 34 & $26 \%$ \\
\cline { 2 - 4 } & Wanita & 97 & $74 \%$ \\
\hline \multirow{4}{*}{ Usia } & $<20$ tahun & 26 & $19,8 \%$ \\
\cline { 2 - 4 } & 21-30 tahun & 92 & $70,2 \%$ \\
\cline { 2 - 4 } & 31-40 tahun & 11 & $8,4 \%$ \\
\cline { 2 - 4 } & $>40$ tahun & 2 & $1,5 \%$ \\
\hline Pendidikan & SMA/Sederajat & 109 & $83,2 \%$ \\
\hline
\end{tabular}




\begin{tabular}{|l|l|c|c|}
\multirow{2}{*}{ Terakhir } & D3 & 6 & $4,6 \%$ \\
\cline { 2 - 4 } & D4/S1 & 16 & $12,2 \%$ \\
\hline \multirow{2}{*}{ Masa Kerja } & $<5$ tahun & 110 & $84 \%$ \\
\cline { 2 - 4 } & $6-10$ tahun & 21 & $16 \%$ \\
\hline
\end{tabular}

Sumber: Hasil Olah Data (2016)

Berdasarkan Tabel 1 dapat dilihat dari jenis kelamin responden bahwa responden wanita yaitu sebanyak $74 \%$ dan pria sebanyak $26 \%$ karena dalam kenyataannya karyawan wanita memang lebih banyak dari karyawan pria. Selanjutnya, dilihat dari usia bahwa responden yang berusia 21-30 tahun lebih mendominasi yaitu sebesar 70,2\% dan hal ini menunjukkan bahwa karyawan di Fashion X didominasi oleh karyawan yang termasuk dalam kategori usia yang sangat produktif. Pada kolom pendidikan terakhir, 83,2\% dari responden telah menyelesaikan pendidikan pada sekolah menengah atas. Kemudian, 84\% responden telah bekerja kurang dari lima tahun, artinya karyawan sudah mengerti paling tidak apa yang menjadi tanggung jawab pekerjaan dan tugasnya masing-masing.

\section{Pembahasan Analisis Deskriptif Budaya Organisasi}

Analisis deskriptif budaya organisasi digunakan untuk menjawab perumusan masalah yang pertama yaitu bagaimana budaya organisasi di Fashion X. Adapun untuk lebih jelas dapat dilihat pada tabel di bawah ini.

Tabel 2

Analisis Deskriptif Budaya Organisasi

\begin{tabular}{lccccc}
\hline & N & Min. & Max. & Mean & Std. Deviation \\
\hline Clan & 131 & 3 & 5 & 3.84 & .391 \\
Adhocracy & 131 & 3 & 5 & 3.69 & .401 \\
Market & 131 & 3 & 5 & 3.74 & .459 \\
Hierarchy & 131 & 3 & 5 & 3.63 & .436 \\
Budaya Organisasi & $\mathbf{1 3 1}$ & $\mathbf{3}$ & $\mathbf{5}$ & $\mathbf{3 . 7 3}$ & $\mathbf{. 3 3 0}$ \\
\hline
\end{tabular}

Sumber: Hasil Olah Data (2016)

Berdasarkan Tabel 2 diketahui bahwa mean budaya organisasi sebesar 3.73 yang berada pada interval 3,41 - 4,20 dan termasuk dalam kategori baik. Standar deviasi menunjukkan angka 0,330 atau 8,85\% dari mean yang memiliki arti bahwa variasi jawaban kecil atau sebagian responden menjawan pernyataan dalam variabel budaya organisasi dengan jawaban yang relatif sama. Variabel budaya organisasi terdiri dari empat dimensi yaitu clan, adhocracy, market, dan hierarchy memiliki mean yang berada pada interval 3,41 - 4,20 dan termasuk dalam kategori baik pula.

Demi mempertahankan visi dan misi yang telah ditetapkan, anggota yang baru bergabung dari awal diberi pengarahan bagaimana budaya organisasi yang berlaku dan wajib dijalankannya sehingga dapat menyesuaikan dengan lingkungannya. Seperti yang telah dipaparkan bahwa Fashion X menerapkan nilai-nilai Islam dalam bentuk kegiatan Islami yang menjadi salah satu budaya yang harus dijalankan oleh seluruh anggotanya. Salah satu bentuk penerapan budaya tersebut adalah melakukan puasa Senin dan Kamis, shalat dhuha, shalat tahajud, membaca Al-Qur'an, dan mentoring. Kegiatan tersebut dimonitori dengan 
adanya aplikasi amalan yaumiah, sehingga jika anggota telah menjalankannya mereka harus mengisi amalan yaumiah tersebut dan hasil amalan yaumiah tersebut menjadi salah satu penilaian kinerja para anggota.

Penerapan budaya organisasi tersebut secara perlahan mampu mengubah perilaku anggota menjadi lebih baik dan menjalankan segala aktivitas dengan ikhlas serta dijadikan sebagai bentuk ibadah. Hal tersebut mempermudah penerapan nilai-nilai inti budaya organisasi yang terdiri dari selalu bersyukur, semangat pentang menyerah, perbaikan berkesinambungan, peduli dalam setiap keadaan, dan memiliki tanggung jawab yang tinggi. Hal ini sejalan dengan fungsi organisasi yang keempat menurut Sobirin (2009: 244) yaitu budaya sebagai alat kontrol karena di setiap organisasi memerlukan sistem pengendalian yang berfungsi untuk mengontrol setiap aktivitas yang terjadi.

Dimensi pertama yaitu clan dengan mean 3,84 merupakan dimensi yang paling besar berkontribusi dalam budaya organisasi. Dimensi clan merupakan dimensi yang menjunjung tinggi kekeluargaan. Sesuai dengan fakta di lapangan bahwa Fashion X dalam menghadapi masalah baik internal dan eksternal diselesaikan dengan cara mufakat. Selain dengan sesama karyawan, rasa kekeluargaan pun dibangun bersama pelanggan dengan cara memperlakukan pelanggan sebagai kerabat sehingga terjalin kerjasama dalam jangka waktu panjang. Meskipun demikian demi mempererat rasa kekeluargaan, anggota di Fashion X perlu untuk meningkatkan komunikasi dalam kerja tim. Robbins dan Judge (2013: 156) menjelaskan adanya tim pada sebuah organisasi tidak terlepas dari keterlibatan anggota sebagi motivator karena tim akan memfasilitasi anggota dalam berbagai keputusan. Dengan adanya kerjasama tim yang tinggi, para anggota akan lebih mudah membuka pikiran-pikiran inovatif dan mempermudah pemimpin untuk memfasilitasi sehingga pengembangan anggota dapat terus ditingkatkan.

Dimensi yang kedua yaitu adhocracy dengan mean 3,69 dan masih berada di bawah mean variabel budaya organisasi. Dalam mengembangkan kemampuan dan fokus pada hal penting telah dilakukan dengan baik oleh Fashion X, hal ini ditandai dengan kegigihan dalam usaha untuk menemukan sumber daya manusia sesuai harapan. Usaha yang telah dilakukan adalah melakukan perekrutan rutin setiap hari Sabtu. Perekturan merupakan hal yang penting karena dengan melakukan perekrutan orang yang memiliki nilai-nilai, dapat mempengaruhi budaya organisasi (Schein dalam Nurjanah, 2008: 46). Akan tetapi dalam pengambilan resiko masih kurang maksimal karena tingkatan resiko setiap departemen berbeda. Deal dan Kennedy (2012: 12) mengungkapkan anggota diharuskan bekerja di bawah tekanan dan dianggap ingin mengambil resiko untuk memenuhi ambisi pribadi mereka serta tujuan organisasi. Pengambilan resiko oleh para anggota dapar dilakukan misalnya dengan membentuk tim-tim kecil kemudian membuat sebuah perencanaan dan dampak dari perencanaan tersebut, sehingga tim dan anggotanya dapat memprediksi resiko yang akan diterima dari perencaanaan.

Dimensi yang ketiga yaitu market dengan mean 3,74. Cameron et al. (2006: 32) memaparkan bahwa budaya market dikendalikan atas kompetisi dan hasrat yang kuat untuk mengantarkan hasil dan mencapai tujuan, dan berpusat pada lingkungan eksternal, pelanggan, dan keuntungan harus didahulukan daripada pengembangan dan kepuasan anggota. Salah satu cara yang telah dilakukan Fashion X dalam mengendalikan pasar adalah mengumpulkan data segmentasi pasar yang dominan untuk selanjutnya data tersebut diolah sehingga mendapatkan pangsa pasar yang tepat. Selain itu, bagian retail memiliki target yang harus dicapai setiap bulannya. Pencapaian hasil dan loyalitas konsumen membuat Fashion X dapat bersaing dengan para pesaingnya. Hal ini dapat dilihat pada prestasi yang didapat oleh Fashion X yaitu Fashion X mendapat peringkat pertama di Top Brands Awards 2015 dalam kategori busana muslim. 
Dimensi yang keempat yaitu hierarchy dengan mean 3,63 dan masih berada di bawah mean variabel budaya organisasi. Hal ini sejalan dengan latar belakang yang memaparkan bahwa belum menemukan pola struktur organisasi yang tepat. Padahal bagi sebuah organisasi yang besar, struktur organisasi sangat penting. Di Fashion X sudah terdapat kebijakan formal yang menjadi pedoman dan harus dipahami, ditaati, dan dilaksanakan oleh seluruh anggota yaitu fakta integritas dan surat perjanjian yang tertera dalam kontrak kerja. Meski demikian, dalam menekankan kepermanenan dan stabilitas belum dapat terlaksana. Hubungan antar anggota tidak hanya dibina dalam lingkungan kerja namun perlu di luar lingkungan kerja, sehingga akan lebih baik jika diadakan gathering setiap satu tahun sekali. Deal dan Kennedy (2012: 4) menyebutkan dalam proses pembentukan budaya organisasi ada yang dinamakan ritual sebagai ungkapan untuk memperkuat nilai-nilai utama organisasi.

\section{Pembahasan Analisis Deskriptif Agilitas Organisasi}

Analisis deskriptif agilitas organisasi digunakan untuk menjawab rumusan masalah yang kedua yaitu bagaimana agilitas organisasi di Fashion X. Adapun untuk lebih jelas dapat dilihat pada tabel di bawah ini.

Tabel 3

Analisis Deskriptif Agilitas Organisasi

\begin{tabular}{lccccc}
\hline & N & Min. & Max. & Mean & Std. Deviation \\
\hline Responsiveness & 131 & 3 & 4 & 3.48 & .301 \\
Competency & 131 & 2 & 5 & 3.21 & .486 \\
Quikness & 131 & 3 & 5 & 3.51 & .428 \\
Flexibility & 131 & 3 & 5 & 3.65 & .320 \\
Agilitas Organisasi & $\mathbf{1 3 1}$ & $\mathbf{3}$ & $\mathbf{4}$ & $\mathbf{3 . 4 6}$ & $\mathbf{. 2 9 3}$ \\
\hline
\end{tabular}

Sumber: Hasil Olah Data (2016)

Pada Tabel 3 menunjukkan bahwa mean agilitas organisasi sebesar 3,46 yang berada pada interval 3,41 - 4,20 dan termasuk dalam kategori baik. Standar deviasi menunjukkan angka 0,293 atau $8,47 \%$ dari mean yang memiliki arti bahwa variasi jawaban kecil atau sebagian responden menjawan pernyataan dalam variabel budaya organisasi dengan jawaban yang relatif sama. Variabel agilitas organisasi terdiri dari empat dimensi yaitu responsiveness, competency, quickness, dan flexibility. Dimensi responsiveness, quickness, dan flexibility memiliki mean yang berada pada interval 3,41 - 4,20 dan termasuk dalam kategori baik pula, sedangkan dimensi competency berada pada interval 2,61 - 3,40 dan termasuk dalam kategori cukup.

Agilitas organisasi didefinisikan sebagai kemampuan organisasi untuk menghadapi perubahan yang sering muncul secara tiba-tiba dalam lingkungan bisnis melalui respon yang cepat dan inovatif yang mengeksploitasi perubahan sebagai kesempatan untuk tumbuh dan sejahtera (Lu dan Ramamurthy 2011: 933). Dalam menanggapi perubahan saat ini Fashion X melakukan berbagai cara untuk tetap bertahan dalam dunia bisnis, yaitu mempertahankan kualitas produk, melakukan inovasi produk, dan terus mengembangkan kemampuan anggotanya.

Dimensi yang pertama yaitu responsiveness. Kebutuhan konsumen berubah-ubah setiap hari karena tuntutan jaman menyebabkan organisasi harus berinovasi mengembangkan 
produk (Lin et al., 2006: 287). Menanggapi hal tersebut salah satunya Fashion X melakukan inovasi pengembangan produk kemeja koko (kemko), dimana kemko ini untuk memenuhi kebutuhan pria yang dapat digunakan formal dan informal. Akan tetapi dalam pengembangan suatu produk, Fashion X tidak melibatkan seluruh departemen dalam koordinasi produk.

Dimensi yang kedua yaitu competency merupakan dimensi yang memiliki nilai terendah dan berada pada kategori cukup. Dalam berkompetisi dengan pesaing, Fashion $\mathrm{X}$ sudah mampu bahkan sanggup menguasai pasar terutama kerudung instan. Akan tetapi pemahaman pengetahuan anggota mengenai siklus hidup produk masih perlu ditingkatkan. Agilitas organisasi diperoleh melalui kemampuan yang diperlukan dengan menggunakan pikiran dan menanggapi kebutuhan pelanggan (Porkiani dan Mohsen, 2013: 1054). Dalam memprediksi produk memang memerlukan pengamatan produk mana saja yang menjadi daya tarik pembeli dan produk mana yang kurang diminati oleh pembeli.

Dimensi yang ketiga yaitu quickness. Fashion X menyuguhkan berbagai macam pilihan produk. Produk unggulannya yaitu kerudung instan yang memiliki karakteristik menyerap keringat, memberikan kesan dingin, tidak menerawang, memiliki berbagai motif dan warna. Dengan karakteristik tersebut, banyak konsumen yang memilih kerudung instan Fashion X untuk digunakan dalam berbagai aktivitas. Dengan demikian Fashion X dengan cepat dapat menemukan preferensi konsumen. Setelah preferensi konsumen ditemukan, maka hal tersebut dapat mencapai kepuasan konsumen sehingga Fashion X dapat memprediksikan produk apa saja yang harus diproduksi secara terus menerus. Akan tetapi dalam peluncuran produk baru, Fashion X memiliki jadwal yang sudah disusun sebelumnya, tetapi dalam kenyataannya masih ada kendala yang menghambat, seperti telatnya pendistribusian dari gudang ke retail karena berbagai alasan.

Dimensi keempat yaitu flexibility yang memiliki mean terbesar. Kara dan Kayis (2015: 189) mengungkapkan bahwa faktor yang mempengaruhi agilitas organisasi adalah ketidakpastian lingkungan. Ketidakpastian lingkungan mengharuskan Fashion X fleksibel dengan perubahan yang ada. Fashion $\mathrm{X}$ melakukan perubahan terhadap produknya namun tetap berpegang teguh pada budaya organisasinya. Setiap ada ide untuk produk baru Fashion $\mathrm{X}$ mengacu kepada budaya organisasinya, apakah produk tersebut sesuai dengan budaya atau tidak. Dengan demikian segala produk baru yang akan diproduksi tetap mempertahankan budaya. Hal ini dilakukan untuk dapat bertahan dalam persaingan dan adaptasi dalam perubahan, sehingga dapat menjadi organisasi yang lincah. Akan tetapi masih ada hal-hal yang perlu diperbaiki untuk lebih fleksibel yaitu proses transfer/mutasi, perampingan alur, dan pendistribusian barang.

\section{Pengaruh Budaya Organisai Terhadap Agilitas Organisasi}

Berdasarkan hasil penyebaran kuesioner kepada 131 karyawan Fashion X, menunjukkan hasil bahwa terdapat hubungan positif antara budaya organisasi dan agilitas organisasi yang kuat sebesar 0,548 yang berada pada nilai koefisien $+0,50$ s.d $+0,69$ (Bungin, 2010: 184) dan memiliki nilai yang positif, artinya hubungan antara budaya organisasi dan agilitas organisasi searah, jika budaya organisasi meningkat maka akan diikuti oleh peningkatan agilitas organisasi.

Budaya organisasi memiliki pengaruh terhadap agilitas organisasi. Hal ini berdasarkan hasil regresi sederhana dengan konstanta $(\alpha)$ bernilai 64,323 dengan koefisien regresi (b) 0,657 sehingga muncul persamaan regresi $\mathrm{Y}=64,323+0,657 \mathrm{X}$. Dari persamaan regresi tersebut, dapat diketahui bahwa setiap penambahan satu angka budaya organisasi dengan koefisien regresi bernilai positif, maka agilitas organisasi akan meningkat sebesar 0,657. Sedangkan, apabila budaya organisasi sama dengan nol atau tidak ada perubahan, maka nilai agilitas organisasi sebesar 64,323. 
Berdasarkan hasil koefisien determinasi diketahui bahwa nilai R Squaresebesar 0,300 atau $30 \%$. Hal ini menunjukkan bahwa $30 \%$ agilitas organisasi dipengaruhi dan dijelaskan oleh variabel budaya organisasi dan sisanya $70 \%$ dipengaruhi dan dijelaskan oleh variabel lain yang tidak dimasukan dalam penelitian ini. Variebel lain sisanya sebesar $70 \%$ yang mempengaruhi agilitas menurut Hamman (2013: 3) meliputi eksekusi, pengiriman, strategi produk, organisasi - termasuk di dalamnya budaya organisasi, dan kepemimpinan. Pendapat lain menurut Wendler (2013: 1168) variabel lain yang dapat mempengaruhi agilitas organisasi adalah budaya organisasi, kekuatan pekerja, pelanggan, kemampuan organisasi, dan teknologi. Ada pun Dalvi et al. (2013: 19) memaparkan bahwa dalam pencapaian agilitas organisasi dipengaruhi oleh kepemimpinan, pelayanan terhadap pelanggan, perubahan organisasi, dan budaya organisasi.

Budaya organisasi memiliki pengaruh yang signifikan terhadap agilitas organisasi. Hal ini sejalan dengan hasil penelitian yang serupa antara lain; Amirnejad dan Milad (2015) yang menyatakan adanya hubungan positif antara budaya organisasi dan agilitas organisasi di National Company of The Oil-Rich Regions in South-Ahvaz. Sejalan pula dengan hasil penelitian Asgari et al. (2014) dengan hasil terdapat hubungan positif yang signifikan antara budaya organisasi dan agilitas organisasi di Agri Bank Provinsi Khuzestan. Hasil penelitian lainnya yaitu AmirKhani et al. (2014) yang menyatakan bahwa ada hubungan positif antara budaya organisasi yang berorientasi pada norma-norma sosial mengenai pengembangan metode perbaikan sistem agilitas.

Dalam mengimplementasikan budaya organisasi untuk meningkatkan agilitas organisasi di Fashion X seperti yang telah dipaparkan di atas, tentu ada konsekuensi yang akan dihadapi. Konsekuensi yang akan timbul adalah penambahan anggaran atau beban pengeluaran untuk beberapa kegiatan. Penambahan anggaran atau beban pengeluaran ini belum tentu dapat diterima oleh bagian keuangan, maka sebelum merencanakannya diperlukan persiapan yang matang dan dapat menunjukkan bahwa output yang akan dihasilkan memang sesuai dengan target. Selain itu konsekuensi lainnya adalah penolakan dari anggota sendiri. Penolakan ini berasal dari dalam diri yang disebabkan oleh rasa aman dan cukup dengan keadaan saat ini, sehingga jika ada aktivitas yang berhubungan dengan peningkatan budaya organisasi yang tidak sesuai dengan diri mereka, akan muncul penolakan yang dapat menghambat aktivitas tersebut. Hal lain yang menjadi konsekuensi adalah waktu. Untuk melaksanakan implementasi budaya organisasi memerlukan waktu yang tidak sebentar, sehingga para anggota harus meluangkan waktu lebih untuk merencanakan strategistrategi baru.

\section{Kesimpulan}

Dari penjelasan yang telah dipaparkan, maka dapat ditarik kesimpulan yang pertama yaitu budaya organisasi di Fashion X berada pada kategori baik. Variabel ini terdiri dari empat dimensi yaitu clan, adhocracy, market, dan hierarchy. Keempat dimensi tersebut tergolong baik dan dimensi clan memberikan kontribusi tertinggi sedangkan dimensi hierarchy memberikan kontribusi terendah.

Kedua, agilitas organisasi di Fashion X berada pada kategori baik. Variabel ini terdiri dari empat dimensi yaitu responsiveness, competency, quickness, dan flexibility. Tiga dari empat dimensi yaitu responsiveness, quickness, dan flexibility tergolong baik dan dimensi competency tergolong cukup. Kontribusi tertinggi berasal dari flexibility dan kontribusi terendah berasal dari competency.

Ketiga, di Fashion X, budaya organisasi berkontribusi $30 \%$ terhadap agilitas organisasi dan diperoleh persamaan regresi $\mathrm{Y}=64,323+0,657 \mathrm{X}$. Koefisien regresi yang bernilai positif menjelaskan jika anggota di Fashion $\mathrm{X}$ mengalami peningkatan dalam penerapan budaya organisasi, maka agilitas organisasinya pun akan meningkat. 


\section{Saran}

Ada pun beberapa saran yang dapat menjadi pertimbangan bagi Fashion X yaitu, pertama untuk dimensi adhocracy dan hierarchy memiliki mean di bawah mean variabel budaya organisasi. Oleh karena itu untuk meningkatkan adhocracy perlu membentuk tim-tim kecil untuk membuat perencanaan pengambilan resiko, sehingga anggota terbiasa dalam mengambil sebuah resiko dalam berbagai situasi. Sedangkan untuk hierarchy perlu diadakan gathering setiap satu tahun sekali.

Kedua, dimensi competency tergolong dalam kategori cukup, maka hal yang perlu dilakukan adalah memfokuskan anggota mengenai pengetahuan siklus hidup produk. Sehingga dapat mempermudah dalam memprediksi dan meramalkan produk untuk periode berikutnya.

Terakhir, pengaruh budaya organisasi terhadap agilitas organisasi tidak begitu besar. Oleh karena itu ada beberapa hal lain yang dapat meningkatkan agilitas organisasi yaitu eksekusi, pengiriman, strategi produk, kepemimpinan, kekuatan pekerja, pelayanan kepada pelanggan, kemampuan organisasi, teknologi, dan perubahan organisasi.

\section{Daftar Pustaka}

Alberts, D. S. and Hayes, R. E. 2003. Power to the Edge: Command, Control in the Information Age. CCRP Publication Series.

AmirKhani, AmirHossein, Fariba TaherianPour, and Ali Ghafary. 2014. "A Survey on the Relationship between Organizational Culture and Improving Agility Methods in Rural Corporation of Water and Sewage in Bushehr Province in Iran". World of Sciences Journal, Vol. 1, No. 7, pp. 94-109.

Amirnejad, Ghanbar and Milad, Zahra. 2015. "The Effects of Organizational Culture on Organizational Agility with Mediator Role of Sharing of Knowledge Headquarters of National Company of The Oil-Rich Regions in South- Ahvaz". Indian Journal of Fundamental and Applied Life Science, Vol. 5 (S3), pp. 1521-1529.

Arikunto, S. 2010. Prosedur Penelitian: Suatu Pendekatan Praktik. Edisi Revisi. Jakarta: Rineka Cipta.

Asgari, Heshmatollah, Noorollah Baziar, and Roohollah Maleki. 2014. "A Study on Relationship among Organizational Culture and Organizational Agility.

Brown, A. 1998. Organizational Culture, $2^{\text {nd }}$ edition. London: Financial Tim Publishing.

Bungin, Burhan. 2010. Penelitian Kualitatif: Komunikasi, Ekonomi, Kebijakan Publik dan Ilmu Sosia lainnya. Jakarta: Kencana Prenama Media Group.

Cameron, Kim S. and Quinn, Robert E. 2006. Dignosing and Changing Organizational Culture: Based On The Competing Values Framework. USA: 7Jossey-Bass.

Cameron K.S., Quinn R. E., Degraff J., dan Thakor A. V. 2006. Competing Values Leadership. Northampton, MA: Edward Elgar.

Cameron, Kim S. and Quinn, Robert E. 2016. "The Competing Values Culture Assessment: A Tool From the Competing Values Product Line”. Universitas of Michigan Regents, tersedia: https://www.academicservice.nl/downloads/download_pdf_culture_assessment_work book.pdf 
Dalvi, Mohamad Reza., Shekarchizadeh, Ahmad Reza and Baghsorkhi, Ghazaleh Rajaei. 2013. "Invesigating of Organizational Agility Component (Culture, Leadership, Organizational Change and Customer Services) on The Organizational Performance Based on The Satellite Model (Snowa Caompany as a Case Study)". G. J. P\&A Sc and Tech, pp. 15-29.

Deal, Terrence and Kennedy, Allan A. 2012. Corporate Culture, The Rites and Ritual of Corporate Life. USA: Wesley Publishing Inc.

Gunasekaran, A. 1999. "The Agile Manufacturing: A Framework For Research and Development." International Journal Production Economics, Vol. 62, pp. 87-105.

Hamman, Michael. 2013. Leading For Organizational Agilitiy Strategy and Design. BigVisible Solutions Inc.

Harraf, Abe., Wanasika, Isaac., Tate, Kaylynn., and Talbott, Kaitlyn. 2015. "Organizational Agility”. The Journal of Applied Business Research, Vol. 31, No. 2, pp. 675-686.

Herujito, Yayat M. 2001. Dasar-Dasar Manajemen. Jakarta: Grasindo.

Kara S. and Kayis B. 2004. "Manufacturing Flexibility and Variability: An Overview". Journal of Manufacturing Technology Management. Vol. 15, No. 6, pp. 466-478.

Lin, Ching Torng, Hero Chiu, and Po-Young Chu. 2006. "Agility Index in The Supply Chain”. International Journal Production Economics. Vol. 100, No. 2, pp. 285-299.

Lu, Y. and Ramamurthy, K. 2011. "Understanding The Link Between Information Technology Capability and Organizational Agility: An Empirical Examination”. Mis Quarterly, Vol. 35, No. 4, pp. 931-954.

Moeljono, Djokosantoso. 2005. Budaya Organisasi dalam Tantangan. Jakarta: Elex Media Komputindo.

Nurjanah. 2008. "Pengaruh Gaya Kepemimpinan dan Budaya Organisasi Terhadap Komitmen Organisasi Dalam Meningkatkan Kinerja Karyawan”. Thesis, Program Studi Magister Manajemen, Universitas Diponegoro.

O’brien, James A. 2005. Pengantar Sistem Informasi, Edisi 12. Jakarta: Salemba Empat.

Porkiani, Masood. And Mohsen Hejinipoor. 2013. "Studying The Relationship between Organizational Intelligence and Organizational Agility in Supreme Audit Court". European Online Journal of Natural and Social Science, Vol. 2, No. 3, pp. 10521060.

Robbins, Stephen P. and Judge, Timothy A. 2013. Organizational Behavior (15 ${ }^{\text {th }}$ Ed.). New Jersey: Prentica-Hall Inc.

Sanchuli, Mohsen and Yazdani, Badrodin Orei. 2015. "The Relationship between Component of Organizational Culture and Agility of Zabol University of Medical Sciences Based on the Denison Organizational Culture Model".Buletin Teknologi Tanaman, Vol. 12, pp. 187-191.

Schein, Edgar H. 2004. Organizational Culture and Leadership, $3^{\text {rd }}$ Edition. San Fransisco: John Wiley \& Sons, Inc.

Sekaran, Uma. 2003. Metode Penelitian Untuk Bisnis. Jakarta: Salemba Empat. 
Sobirin, Achmad. 2009. Budaya Organisasi, Pengertian, Makna, dan Aplikasinya dalam Kehidupan Organisasi Edisi Kedua. Yogyakarta: UPP STIM YKPN.

Soedjono. 2005. "Pengaruh Budaya Organisasi Terhadap Kinerja Organisasi dan Kepuasan Kerja Karyawan pada Terminal Penumpang Umum di Surabaya". Jurnal Manajemen \& Kewirausahaan, Vol. 7, No. 1, Hal. 22-47.

Sugiyono. 2013. MetodePenelitianKuantitatif, Kualitatif, dan R\&D. Bandung: Alfabeta.

Suparjati. 2000. Tata Usaha dan Kearsipan. Yogyakarta: Kanisius.

Wendler, Roy. 2013. "The Stucture of Agility from Different Perspectives". Federated Conference on Computer Science and Information Systems, pp. 1165-1172.

Werner, A. 2007. Organisational Behaviour: A Contemporary South African Perspective. Pretoria: Van Schaick.

$\mathrm{Yu}$, Tianyuan and Nengquan Wu. 2009. "A Review of Study on the Competing Values Framework". International Journal of Business and Management, Vol. 4, No. 7, pp. $37-42$.

Zhang, Z. and Sharifi H. 2000. "A Methodology for Achieving Agility in Manufacturing Organizations." International Journal of Operations and Production Management. Vol.20, No. 4, pp. 496-512. 
